\title{
Erratum to: Synthese special issue: representing philosophy
}

\author{
Colin Allen • Tony Beavers
}

Published online: 6 November 2009

(C) Springer Science+Business Media B.V. 2009

\section{Erratum to: Synthese \\ DOI 10.1007/s11229-009-9664-Z}

The affiliation of Collin Allen should read:

Department of History and Philosophy of Science, Indiana University, Goodbody Hall 130, Bloomington, IN 47405-7000, USA.

The online version of the original article can be found under doi:10.1007/s11229-009-9664-z.

C. Allen

Department of History and Philosophy of Science, Indiana University, Goodbody Hall 130,

Bloomington, IN 47405-7000, USA

e-mail: colallen@indiana.edu

T. Beavers $(\varangle)$

Department of Philosophy and Religion, The University of Evansville, 1800 Lincoln Avenue, Evansville, IN 47722, USA

e-mail: afbeavers@gmail.com 